\title{
Bodies of Texts: Women Calligraphers and the Elite Vernacular Culture in Late Chosŏn Korea (1392-1910)
}

\section{KSENIA CHIZHOVA}

Men's references to women's writing in vernacular Korean script never term this practice "calligraphy," and yet articles of women's intricate brushwork reveal that in late Chosŏn Korea (1392-1910) this was a highly aestheticized practice with recognized social importance and a meticulous training process. This article captures the moment when vernacular Korean scriptural practices ascended the elite canon, which resulted in the emergence of high vernacular culture. It historicizes the gendered logic of representation in a male-authored historical archive to uncover the contours of a women-centered vernacular aesthetic canon that assumed a status of prestige alongside male culture in literary Chinese. The article unravels the meaning of the term "calligraphy" when it is applied to women's vernacular handwriting and ponders the connection between women's bodily discipline, productive work, and exquisite vernacular brushwork. This opens an alternative perspective not only on the gender politics of the Choson society but also on the culture of the time, which is hitherto seen as dominated by a male-centered literary Chinese canon.

Keywords: Chosŏn Korea, elite vernacular culture, lineage novel, vernacular Korean calligraphy, women's culture

T OMEn's BODIES AND THE productive corporeal work they performed became central to women's identities in the latter half of the Chosŏn dynasty (1392-1910). While throughout Korean history women's lives much depended on their relationship with men, in the seventeenth century the Chosón society assumed a rigid patrilineal structure with a distinctive ideal of female domesticity. These changes were felt most acutely by the elite women who are also central to this study: having lost their ability to inherit property and divorce, as well as their freedom for unconstrained movement outside their homes, women spent their lives in the domestic quarters of their husbands' families. In the domestic space, women's bodies created the dense fabric of habitation, attachment, and care.

This article will show how the dexterous female bodies created the objects of everyday use and enacted relational hierarchies of the patriarchal kinship system, but more importantly - a hitherto little recognized aspect of women's lives central to this studywere implicated in the creation of a sophisticated vernacular canon of calligraphy and literature that thrived alongside literary Chinese culture, the prerogative of educated 
males. I will trace the boundaries of the cultural space that arose at the intersection of women's legislated corporeality and creative engagement with the world of letters. As a result, the gender politics of the Chosonn society and the dynamic vernacular culture, mostly known through male-authored sources, can be observed from the perspective of women's lives and activities.

While the exterior of cultural eminence of the lineage depended on its male members' prestigious office holding and literary fame, life in populous domestic communities was sustained by the so-called "womanly work" that defined women's social identities. Women brewed soy sauce, prepared meals for ancestral worship ceremonies, and provided seasonal outfits for the entire family, while also attending to a variety of domestic bodies - growing bodies, decaying bodies, and dead bodies. In detailed instructions, Kim P'yŏngmok (1819-91) offered the following advice to future mothers: "Say, if a woman is with a child, [she] does not sleep askew, nor does she lean to one side while sitting or put her weight on one leg while standing" (Hong Hakhŭi et al. 2013, 6:277). Women were also expected to be intimate with decaying bodies. Sŏng Haeŭng (17601839) writes that his mother took utmost care of her own mother-in-law on her deathbed: "When my grandmother suffered from dysentery and her symptoms grew worse, Mother tasted her excrement in order to obtain a diagnosis for her illness. But my grandmother was ultimately unable to recover" (1:188). The bodies of the deceased were similarly entrusted to women's hands. Madame Cho of Hanyang (1794-1852), according to the testimony of her husband, Hŏ Chŏn (1797-1886), dressed the remains of her mother-in-law and Hŏ Chŏn’s own mother with unfailing care: "When it came to funerary preparations for Mother, of combing the corpse's hair, holding of the funerary shroud, and washing the corpse, my wife handled everything herself. The dressing of the corpse, too, was handled by her alone. She did not let any female servants near" (5:152). The emphasis Hŏ places on his wife's dedication, in that she performed the necessary rites for sending off the deceased in her very person, emphasizes the value of women's bodily devotion.

Women's diligent bodies of devotion, always ready at the service of their household members, were often celebrated in male-authored commemorative texts that appeared in quantity after the seventeenth century. These texts offer perhaps the most extensive glimpse of women's everyday experience, all the while outlining the repertoire of prescriptive womanly conduct. Importantly, while celebrating a variety of women's embodied skills, commemorative texts also often praise women's ability to write vernacular Korean in a well-trained hand. Women's writing, however, is never called calligraphy (sŏ 書), an art form reserved for men's practice; at most, the strokes of a woman's brush are said to be orderly and vigorous.

In excess of its aesthetic aspect, male practice of calligraphy in literary Chinese was a matter of moral cultivation, and even statecraft-it was the essential art that embodied the cultivated nature of the person and the moral clime of the state, reflected in tangible, somaticized brushstrokes. King Chŏngjo (r. 1776-1800), for instance, sought to reform the calligraphic styles of his time, thus standardizing this scriptural medium of the public sphere. Aesthetic and moral cultivation were central to the learning careers of elite men, and while women were also subject to rigorous comportment standards concerned with various forms of bodily discipline-chastity, circumspection in speech and conduct, and diligent application to variegated household tasks_education for its own 
sake was never a priority in women's lives. Women's regular brushstrokes mentioned in male-authored sources, therefore, neither revealed the moral character of the scribe nor were connected to the matters of public valence. Still, behind the elegant latticework of vernacular Korean letters stood ambidextrous women's bodies that mastered the canon of patriarchal corporeal normativity but also verged into the space of aesthetic training.

Instead of drawing a map of the multilayered sociolinguistic practices of Chosŏnitself a vast ground for theoretical study-this article outlines the specific historical process through which vernacular culture acquired connotations of social prestige and thus itself became stratified. To this day, vernacular Korean writing is largely understood in conjunction with the unsophisticated popular literature or mundane scribal practices such as note-taking and correspondence that had little value outside their practical purpose. This article shows that vernacular Korean calligraphy and vernacular lineage novels attained extreme aesthetic refinement as ingredients of the cultural proficiency of the most exclusive elites - women who belonged to civil lineages (yangban) and who were educated if not always affluent.

The term "vernacular" here means two things. Quite literally, it designates writings in the Korean script-a vernacular development within the culture of Chosŏn that prioritized literary Chinese scriptural practices. More broadly, "vernacular" certainly is imbued with the connotations of a local and therefore more circumscribed domain, but in a sense that is different from the well-known Sanskritic cosmopolitan-vernacular model developed by Sheldon Pollock (2006). The main difference is that Korean vernacular practices occurred in a script that had social and cultural connotations that distinguished it from the cosmopolitan literary Chinese script. From the moment of its creation in the fifteenth century, vernacular Korean script, strongly associated with women's literacy and private culture, was excluded from the high aesthetic canon. Vernacular Korean practices, therefore, did not merely localize and vernacularize the high universalist language-literary Chinese-but were instead founded on radically different premises.

In China’s case, as Patrick Hanan $(1981,4)$ notes, “The critics who praised vernacular works praised them, generally, in elegant Classical Chinese; their concern was with literary merit, not with the literary medium, or if with the literary medium, then only as used in that genre." In Chosŏn Korea, vernacular fiction was hardly ever praised in literary Chinese-novels that thrived in vernacular were ostracized as a dangerous enchantment for weak minds, while handwriting in vernacular Korean was denied aesthetic value precisely because it was executed in vernacular Korean script that had no public significance. Unlike in Japan, where some vernacular literary practices, such as waka or monogatari, were canonized (Shirane 2003), this was not the case in Korea. At the same time, vernacular lineage novels and vernacular calligraphy flourished in women's quarters, where they developed into an elite vernacular canon that garnered considerable prestige alongside male culture in literary Chinese. Just what kind of canon it was and what light it sheds on canon formation and the emergence of East Asian vernaculars, it is this article's purpose to show.

In the argument that follows, I first outline the politics of gender that orchestrated the disparate visibility of men and women in Chosonn society and culture, ponder on the striking similarities in the calligraphic training of men and women, and foreground the calligraphic significance of women's vernacular brushwork. Finally, I pinpoint the 
unique intersection of vernacular calligraphy and the lineage novel, showing how women's manuscript-making activity defined the cultural prestige of this literary genre that elaborated the major historical transformation of premodern Korean society-the establishment of the patriarchal lineage structure that took place around the seventeenth century.

\section{The Politics of Gender in Language: The Womanly Art of Vernacular Calligraphy}

In the late eighteenth century, Yi Tŏngmu (1741-93), a prolific scholar and writer, ventured an explanation for the glaring silence surrounding women's scriptural practice. In his short text, Tongguk puin nŭngsŏ 東國婦人能書 (Women calligraphers of the eastern country), Yi wrote: "Before the promulgation of the Correct Sounds to Instruct the People (Hunmin chŏngŭm 訓民正音), many women were able to write in a good hand, methinks. However, beginning with Sejong's reign [ $r$. 1418-1450], even if some women are famed for their poetry, hardly any woman is known for her calligraphy" (Yi Tŏngmu 2000, 259:4). Yi’s understanding of calligraphy is revealingly limited to the practice of writing in literary Chinese. After the promulgation of the Correct Sounds to Instruct the People (the name for the Korean alphabet at the time of its creation) in 1446 during the reign of King Sejong, women began writing almost exclusively in vernacular Korean. Yi Tŏngmu and his educated male contemporaries saw little value in vernacular Korean culture: only compositions and calligraphy in literary Chinese, monopolized by elite men, constituted the realm of true aesthetic significance par excellence.

The society of Chosŏn comprised an array of sociolinguistic practices, of which two are central to this discussion - the high literary Chinese canon and the elite vernacular Korean culture-which were quite interrelated in practice, even if disparate in prestige. Unspoken but written literary Chinese was the language of legislation, official histories, government bureaucracy, and educated men's writing. Men would resort to writing in vernacular Korean when exchanging letters with women of their families, and in some cases men composed books of conduct for the benefit of their marrying daughtersalso in Korean. ${ }^{1}$ Writing in vernacular, however, did not contribute to a man's cultural capital. Literary collections compiled posthumously to preserve a learned man's legacy never included any texts in vernacular Korean. Women, on the other hand, used vernacular Korean freely and not without pride, writing letters, poetry, and miscellaneous practical tips, and also copying books of fiction.

The edict of the promulgation of the Korean alphabet reveals that the script was devised as a simpler and more effective method of reflecting the phonetics of the Korean language, to provide a medium for learning and communication to all those who could not master literary Chinese-to women and lower classes (Ch'oe 1993). Whether or not truly demotic in design, ${ }^{2}$ the vernacular Korean alphabet might

\footnotetext{
${ }^{1}$ The best-known text of a father's advice to his daughter in Song Siyŏl's Kyenyŏsŏ (Instruction to my daughter). For a partial English translation, see Song (2000).

${ }^{2}$ Chŏng Taham (2009) suggests that rather than a nativist impulse to capture and communicate the spoken language, the Korean alphabet was devised as a more effective means of reflecting the changes in the Chinese language- - the linguistic manifestation of Korea's place in the Chinese
} 
indeed have required fewer resources to master than Chinese logographs, but this alone cannot explain its inferior cultural status. It is rather the politics of gender adopted by the Chosŏn state that instituted distinct cultural spaces occupied by writings in literary Chinese and vernacular Korean.

Before beginning to write exclusively in vernacular Korean script, women were well versed in literary Chinese, but references to women's writing in literary Chinese gradually disappeared after the seventeenth century-with the exception of the few women mavericks who composed poetry and even Confucian treatises in literary Chinese (Kim-Renaud 2004). In the seventeenth century, Confucian ideology took root in premodern Korean society, which became gradually transformed into a patriarchal lineage structure with patrilineal succession. The politics of gender was instrumental in this change, as it secured the distinction between the public/outer and domestic/inner spheres, reserved respectively for men and women. Women lost their ability to inherit property or divorce (Deuchler 1992); their lives consigned to the domestic quarters of their husbands' families, women were also not expected to participate in the public literary culture, although there were certain exceptions to this rule. ${ }^{3}$ The newly instituted ideal of female domesticity and gender-marked politics of space were also replicated in the stratification of the linguistic field. Historian of premodern Korea JaHyun Kim Haboush $(2002,223)$ has noted that the male, public sphere of legislation, historiography, and Confucian philosophy articulated fundamental ideological maxims in literary Chinese, which inaugurated it as the literary language par excellence. The script-literary Chinese as the symbol of the hegemonic sphere and vernacular Korean that gradually gained a strong association with women's culture-functioned as one among other culturally existing symbols that marked gender identities in premodern Korea. ${ }^{4}$

That Yi Tŏngmu and his male contemporaries refused to apply the term "calligraphy" to women's vernacular handwriting is another token of the overarching scriptural hierarchy mapped upon the Confucian gender norms. At the same time, male-authored records capture the aesthetic and social significance of women's handwriting, even when they fail to account for the fact that vernacular culture has produced an extensive aesthetic canon that commanded recognizable cultural prestige.

Women's cultivation of their handwriting in the vernacular script came to the attention of Yi Tŏngmu's slightly older contemporary, Yi Ok (1760-1815), who accorded

world order. Along these lines, the creation of the Korean alphabet would solidify Chosorn's place within the Sinosphere rather than strengthen its autonomy therein.

${ }^{3}$ It is important to note that even despite the injunction of domesticity women were active in the legal space, submitting vernacular Korean petitions. Jisoo Kim's $(2015,54-73)$ discussion of petitioning activity complicates our understanding of the use of the Korean script, highlighting another avenue by which women claimed public valence for their use of vernacular script.

${ }^{4}$ Among the four elements crucial to Joan Scott's definition of the politics of gender, script-vernacular Korean or literary Chinese-was one of the culturally existing symbols that marked gender identities in premodern Korea. As Scott $(1999,42)$ has famously written, gender as a "constitutive element of social relationships based on perceived difference between the sexes" and as "primary way of signifying relations of power," is constituted by four interrelated elements: culturally existing symbols; strategies of their interpretation; social institutions that produce and reproduce the politicized discourse of gender difference; and, finally, the subjective identity as the site of inscription, where the recognition of oneself as a gendered being takes place. 
women's practice of writing vernacular Korean letters a name with particular attention to style. In his literary Chinese poem Yiŏn 俚諺 (Maxims), among the etudes that described marriage preparations, women's life after marriage, and the relationship between husband and wife, Yi wrote the following quatrain:

Since you learned the palace style calligraphy early on,

You crown the round letter with a handsome sharp stroke. ${ }^{5}$

Your parents-in-law delight in your writing;

"It is that of a female scholar-official!" they say. (quoted in Im 1988, 125)

Yi Ok renders a woman's writing prowess as a desirable and reputable achievement from the perspective of her parents-in-law, who embody ultimate authority in the life of a married woman. The poem's use of a specific term—“palace style” (kungch'e 宮體)—is, moreover, a rare and intriguing instance of classifying women's writing style so precisely.

Palace women are believed to be the creators of the so-called palace style of vernacular writing. This was the first truly aestheticized vernacular writing form (Haboush 2008) that emerged after the originally square vernacular graphics evident in the fifteenthcentury state-sponsored print publications were appropriated into daily epistolary use and thus softened and rounded in the fifteenth and sixteenth centuries (Yesul ŭi chŏndang 1994). Entering service at the royal precincts as young girls, palace women who belonged to the secretariat received rigorous calligraphic training in order to write letters of greeting exchanged between royal family members (munan 門安), keep royal household registries ( $p a l g i$ 件記), and copy books for the palace library (Haboush 2008; Kim Yongsuk 1987). ${ }^{6}$ There are virtually no records that would tell us about the lives and work of the Korean palace women, but the latticework of linked cursive letters of their creation quickly spread outside the palace to become a necessary ingredient in the education of girls from upper-class families (Im 1988, 125). Calligraphy was a task and a skill that secured palace women's livelihood-they were professionalized subjects who were not allowed to marry and thus existed outside kinship networks. Palace women's calligraphy traveled in the letters they sent outside the palace walls ${ }^{7}$ and also in the volumes of palace manuscripts that were taken along by royal princesses as part of their dowry upon marriage. ${ }^{8}$ Outside the palace, women's lives were unimaginable

${ }^{5}$ The passage refers to the letter " $O$ " (iŭng) of the Korean alphabet. This letter could be written either as a simple circle, or as a circle crowned with a vertical stroke, the latter being a sign of a more elaborate writing style.

${ }^{6}$ Changsŏgak repository, now located at the Academy of Korean Studies in Songnam, is the largest, though not exclusive, repository of the texts previously held at the royal library. For other texts written in vernacular palace style calligraphy, see Academy of Korean Studies (2000). Photographs of multiple works of this holding are also available in Academy of Korean Studies (1992).

${ }^{7}$ Veritable Records (Sillok 實錄) of Chosŏn mention that in the year of 1485 palace women were prohibited from sending epistles written in the Korean script out of the palace, which suggests the existence of extensive epistolary networks (see Kim Ilgŭn 1971, 27). A later example of letter exchange between a palace woman, Matron Ha, and the wife of Yun Yonggu (1853-1937) can be found in Haboush $(2009,223)$.

${ }^{8}$ On including lineage novels in the royal dowry, see Kim Tonguk $(1971,40)$. One of the margin marks in the 1880 manuscript of The record of two heroes: Brothers Hyon states that it was transcribed from a volume produced at the royal palace (Yi Tawŏn 2001, 39). 
outside kinship networks: elite women were expected to marry, and their lives and calligraphic practice were determined by the structures of kinship obligation. Thus, while the first aestheticized form of vernacular handwriting appeared in the semi-professionalized activity of the palace women, outside palace walls vernacular Korean calligraphy was a practice tightly interlaced with the structure of kinship networks and women's roles therein.

Although records show that elite women received education, learning was never a priority for women (Deuchler 2003). It was not learning, but productive work such as brewing soy sauce and wine, and proper bodily comportment, such as chastity and circumspection in speech, that defined women's identity in Chosŏn. Francesca Bray $(1997,2)$ explains the term used to refer to this type of work in Korea and China — "womanly work" (Korean: yŏgong, Chinese: nügong 女工)—to be a technology of "shaping and transmitting ideological traditions" through bodily habit that produces objects with social meaning and embodies human relations. Womanly work, thus, becomes a cultural symbol, a code that bespeaks the subject's position in the gendered system of intelligibility.

When references to women's vernacular calligraphy appear in commemorative genres, writing, bodily discipline, and womanly work constitute a semantic continuum. The following lines were written by Yi Chae (1648-1746) about his aunt, Madame Yi of Yŏn'an: "[Lady Yi] took pleasure in every kind of womanly work [女工], doing everything with great dexterity, and bringing each task to perfection. Moreover, she wrote in elegant hand. To all the women of the house, a piece of her writing was a treasure" (Hwang et al. 2010, 6:107). In an epitaph that Song Siyŏl (1607-89) wrote for a girl who died in her youth, he noted, "You learned all womanly work [女工] by eight $s e,{ }^{9}$ and there was nothing you could not do. You wrote letters instead of your mother, and she was never dissatisfied [with your writing]" (Chŏng Hyǒngji 2006, 1:227). ${ }^{10}$ In the words of her son, An Chŏngbok (1721-91), Madame Yi "at six se learned the vernacular script that records the sounds of our language; at seven se wrote letters instead of her elders, writing with great affection, beyond the mere officious greetings, which pleased each [addressed] person. Her skills of womanly work surpassed those of everyone else" (Hwang et al. 2010, 8:284). A woman's ability to write, continuing the list of other practical skills collectively termed "womanly work," thus fell within the repertoire of gender-marked bodily competences.

Women's epistolary calligraphy, similarly, was directly linked to women's role of maintaining the immediate social circle of their families (see figure 1). Kim Chusin (1661-1721) wrote the following in the tomb inscription composed for his aunt, Madame Yi of Hansan:

Lady Yi was extremely diligent and even in her advanced age she never put away her weaving instruments. When exchanging letters or sending food or clothing to someone else, she would always write the notes herself. The strokes of her

\footnotetext{
${ }^{9}$ In premodern Korea, a person's age would be counted in se. A person would be one se of age at the time of birth, with another se being added in the new year. Thus a person of eight $s e$ would be six or seven years old by Western count.

${ }^{10}$ Also cited by Yi Kyŏngha $(2005,227)$, who similarly notes the connection between women’s embodied skills and vernacular handwriting.
} 


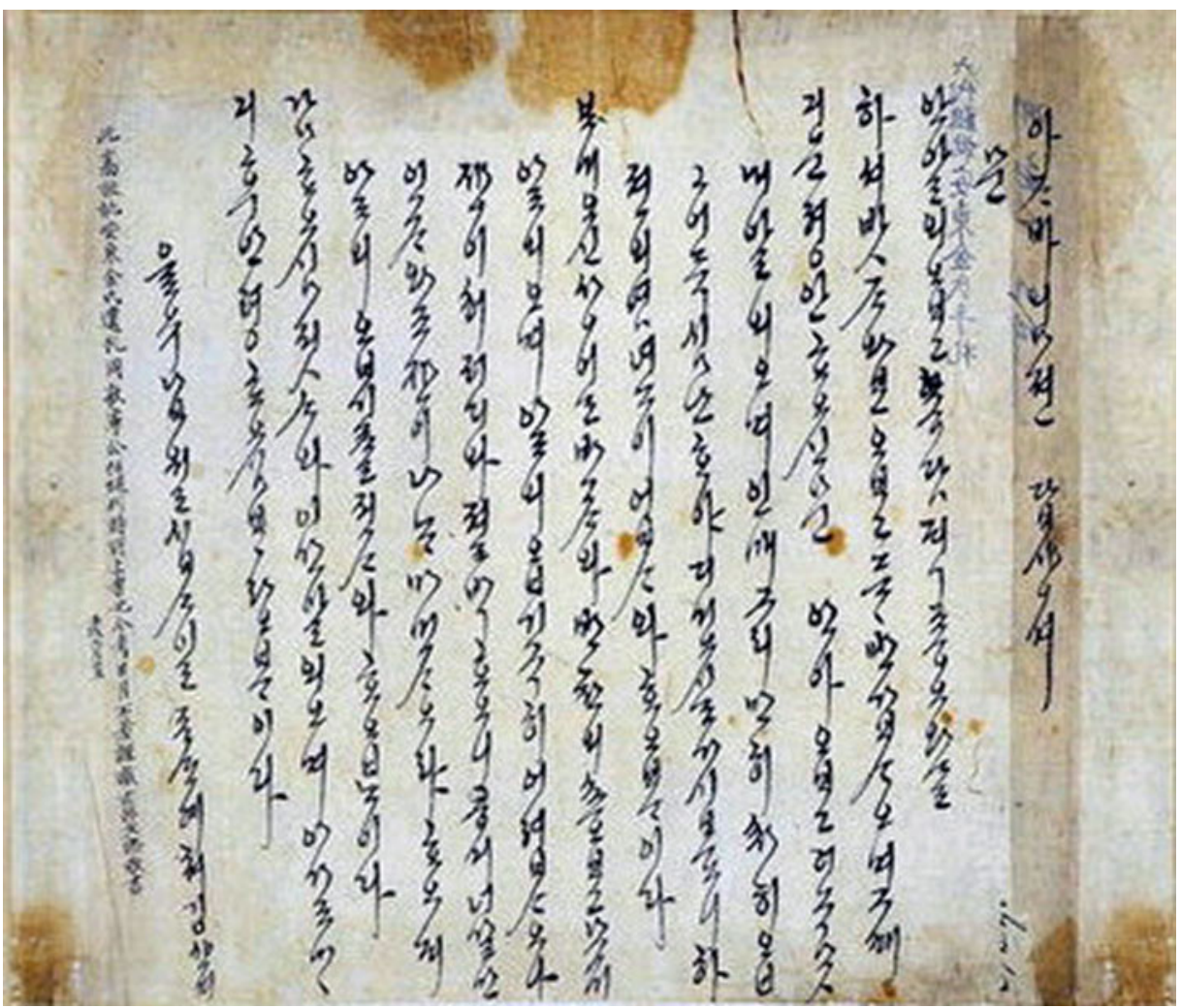

Figure 1. A vernacular Korean letter by Kim Hoyŏnjae. In Sŏnse ŏndok (Ancestors' vernacular epistles). Taejŏn History Museum, original. The Academy of Korean Studies, microfilm. MF 35-11353.

brush were vigorous and upright, with not a single letter askew. Sometimes she would spend days on end [writing notes], but without ever showing so much as a sign of fatigue. (Hwang et al. 2010, 7:84) ${ }^{11}$

In this account, the praise of Madame Yi's calligraphy, notably, follows a remark on her diligent application to weaving, and it is also linked with her social prowess-she takes utmost care to remember and maintain her immediate social network by sending gifts and writing accompanying notes in beautiful calligraphy.

As a laborious and consuming activity, women's writing could also serve as a tangible token of filial piety, or devotion to one's parents in the case of men and to parents-in-law in women's case. Among various performances of filial piety, bodily offerings that inflicted harm on the filial subject were the most convincing (Wang 2012). In a tomb inscription for his aunt Madame Min (1678-1741), Min U'su (1694-1756) drew the connection between women's writing and filial piety:

Master Yi [Madame Min's husband], in his late years, retired to the countryside to take care of his elderly parents. [Madame Min’s] mother-in-law, Madame

\footnotetext{
${ }^{11}$ Also cited by Yi Kyŏngha $(2005,228)$.
} 
Hwang, in her advanced age suffered from insomnia, and thus took to vernacular fiction. Master Yi would not leave her side even for a moment, reading aloud for Madame Hwang. Madame Min took his place a number of times and then completely replaced him in this task. Later, if there were books that were of interest to Madame Hwang, Madame Min would do her best to borrow them. Since she could not keep the borrowed books too long, Madame Min would spend long nights copying them herself. In the end, her eyes were so worn that a few times she was on the verge of going blind. In this way Madame Min made utmost effort to please Madame Hwang. (Hwang et al. 2010, 1:501)

A laborious corporeal task with social meaning - the semantic range of women's handwriting was certainly distinct from male connoisseurship and self-cultivation achieved through the practice of literary Chinese calligraphy.

Much of our knowledge about women's lives in Chosŏn Korea comes from male-authored sources that reveal considerable ambiguity. Men propagate the womanly ideal that rests on cultivated corporeality and domesticity, but at the same time register women's training in vernacular handwriting and its recognizable aesthetic and social value. These sources, thus, reveal the tension between the validated cultural significance of women's vernacular brushwork and the status of the literary Chinese as the exclusive script of high culture. The term "calligraphy" retroactively applied to women's refined handwriting consolidates the contours of women's culture hinted at in the surviving articles of women's calligraphy and in the reticent acclaim that men spare for women's handwriting. Within the domain of women's calligraphic practice, the aesthetic element of women's handwriting was distributed across the registers of bodily discipline and social value. In the sections below I further elaborate on the three aspects that allow us to speak of vernacular calligraphy rather than simple handwriting: its aesthetic dimension, social value, and meticulous training procedures.

\section{Learning to Write: Men and Women}

In adulthood men and women were supposed to inhabit distinctive areas of premodern Korean society_-public and domestic_-and the meaning of calligraphy in men and women's lives differed. While for men calligraphy in literary Chinese became a means of moral self-cultivation and a highest aesthetic achievement, for women, writing vernacular script in elegant hand was a form of bodily discipline and an activity with practical social value. Curiously, in the earlier stages of their education, boys and girls learned writing in environments that were mixed in terms of gender and script, even using similar learning practices. Boys learned their first letters, both literary Chinese and vernacular Korean, from their mothers, while doting fathers and grandfathers often taught their daughters and granddaughters literary Chinese and poetry composition.

Madame Yun of Haep'yŏng, mother of famed Chosŏn novelist Kim Manjung (163792), was a well-known figure during her time. Kim Manjung’s Sŏnbi chŏnggyŏng puin haengjang 先妣貞敬夫人行狀 (Posthumous biography of my honorable late mother) celebrated Madame Yun's exceptional virtues and circulated widely outside Kim Manjung’s household. In this posthumous biography, Kim Manjung recollected the difficulties his mother endured in order to educate her sons after the death of her husband: 
Not much time has passed since the disaster [the Manchu Invasions (1623, 1636)], and no matter how hard one tried, books were difficult to come by. My mother exchanged grain for books like Mencius and The Doctrine of the Mean. My elder brother was particularly fond of The Zuo's Commentary on the Spring and Autumn Annals and when he heard that someone was selling this book and saw that it came in many volumes, he agreed to the purchase even before asking the price. Mother then cut a bolt of silk in order to pay for the books - we really had nothing else to offer as payment. If some of our neighbors worked at the Office of Special Counselors, Mother would ask them to borrow the vernacular exegeses to the Four Books and The Book of Songs, which she would then copy by hand. Her letters were like stringed pearls-exquisite and delicate, with not a single stroke remiss. (Chŏng Hyǒngji et al. 2006, 1:357)

Describing the tactile vividness of the book culture at the time when books were scarce, this note singles out the decisive role Madame Yun played in her son's early education: she transcribes the books by hand, cuts a bolt of silk to organize a payment, and uses the network of her connections to procure learning materials. Madame Yun's calligraphy, the first model for her sons' own handwriting, is also given due recognition.

Madame Yun's calligraphy was again mentioned in another posthumous biography, composed this time by her grandson, Kim Chin'gyu (1658-1716). Kim Chin'gyu recollected the words of his own father and Kim Manjung's brother, Kim Man'gi (1633-87): "Having lost his own father as a child, my father learned letters directly from my grandmother [Madame Yun], and in his late years he would ask his own grandchildren, 'If you had learnt calligraphy from a woman, like I did, would your brushstrokes be the same as mine?"” (Hwang et al. 2010, 1:446). It is likely that Kim Man'gi refers here to literary Chinese calligraphy, as writing in vernacular Korean was never considered a great accomplishment for a man of letters. He also takes apparent pride in the fact that, even under a woman's instruction, his calligraphy lacks nothing in comparison to the handwriting of his male peers. In this way, Madame Yun and her aptitude as calligrapher and educator became a memory that was cherished across several generations in her family.

The fact that Madame Yun herself was able to develop a fine hand both in literary Chinese and vernacular Korean can be explained through numerous other references that intimate that girls were wont to receive instruction in literary Chinese from elder male members of their families. Pak Sedang (1629-1703), for instance, in the tombstone inscription for his granddaughter, noted that her father and his own son, suffering from a protracted illness, taught his daughter literary Chinese calligraphy, and as a result, "her brush was forceful and vigorous, unlike the writing of other women's small and weak hands" (Chŏng Hyǒngji et al. 2006, 3:99).

For men and women alike, family instruction was a crucial resource for calligraphic training. Yi Tŏngmu (1741-93), who not only left a most captivating account of everyday life in traditional Korea but also was a prominent scholar of practical learning, and a scholar at the Royal Library responsible for the compilation of important literary collections, recalled fondly how his own father copied The thousand-character classic for him and his younger brother, Yi Kongmu (Yi Tŏngmu 2000, 258:135). Yi Tŏngmu then perpetuated his calligraphic knowledge within his own family by constantly commenting on the 
calligraphy of his nephew. After receiving another of his nephew's epistles written in grass script, Yi Tŏngmu wrote, "the letter I just received is extremely difficult to read, and although [the writing style] is intricate, [looking at it] one feels as if one has fallen into a bush of thorns and one cannot understand anything." Yi Tŏngmu cautioned his nephew against unnecessary display of calligraphic prowess-harmony and simplicity of brushstrokes and not forced artistry, wrote Yi, is the most convincing token of one's skill (258:237).

In addition to family instruction, men relied on their intellectual networks in order to benefit from the advice of expert calligraphers. Kim Chŏnghŭi (1786-1856), perhaps the most renowned calligrapher of late Chosŏn, wrote that he received numerous requests for letters, since they would then be used as models to emulate his hand (Yi Insuk 2005, 57-60). He himself was also wont to conduct calligraphy contests for his disciples, where he would later correct, and comment upon, their brushwork (Sim Hyŏnsŏp 2009, 66-73).

In a similar vein, women relied on their domestic networks to perfect their vernacular Korean calligraphy, using letters and books as the main learning primers. Sin Kyŏng (1696-1766) wrote the following about his mother:

My mother's brush strokes were elegant, firm, and measured, so all women at that time sought to emulate her hand. In writing letters, she focused on communicating just the gist without wasting paper for artful verbiage. All who received her letters relished them and longed to model them, but my mother had not the slightest liking for boasting about it. (Hwang et al. 2010, 3:221)

Along with a reticent appreciation of his mother's beautiful handwriting and stylish prose, Sin Kyŏng reveals that women's epistles, as artifacts of fine vernacular calligraphy, were appreciated in women's circles and used as style guides.

Another way for women to learn calligraphy was by copying fiction. A surviving undated sketchbook includes carelessly copied excerpts of fiction and poetry alongside some items of practical advice, such as the almanac of most auspicious dates for placenta burial (Yunssi haengjang, n.d.). ${ }^{12}$ This sketchbook is written in different hands, and along the lines written in well-trained cursive brush, there are jottings in uncertain, childish letters (see figure 2). The persistence of the aspiring calligraphers is striking, as wobbly brushwork patiently follows the playful, flowing letters of the skilled tutor through pages upon pages of this sketchbook. It becomes apparent at a glance that cultivation of vernacular writing was a much-desired skill, acquired through assiduous application. The selection of texts used for brushwork practice-a woman's posthumous biography and the practical advice for placenta disposal-points to the activity of female scribers, while the different level of skill displayed in different excerpts illuminates the paradigm of communal learning, in which multiple scribes would share one sketchbook.

As the following section will show, men and women were also wont to copy vernacular Korean novels together-boys, therefore, would practice vernacular Korean

\footnotetext{
${ }^{12}$ This volume lacks any coherent organization, and the title is given after the first copied text, which happens to be Kim Manjung's Posthumous biography of my late mother.
} 


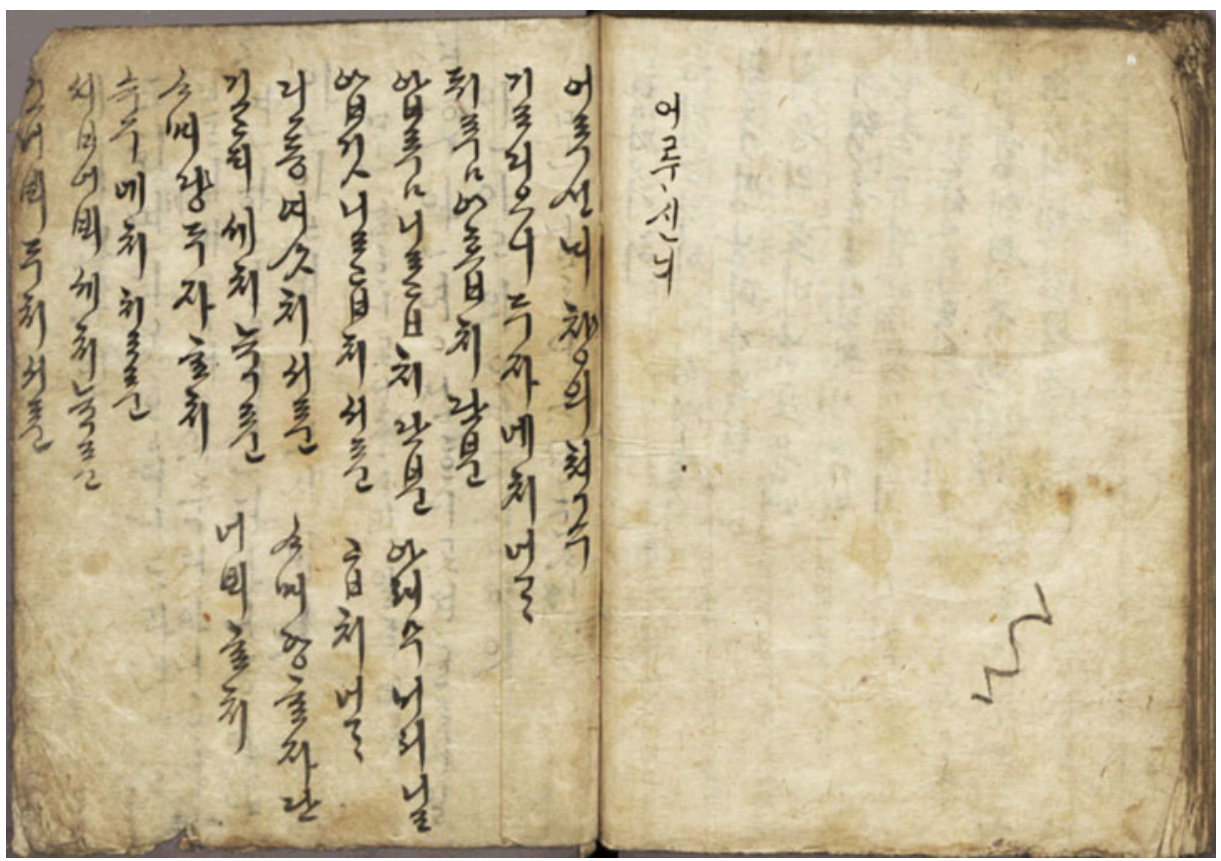

Figure 2. Yunssi haengjang (The posthumous biography of Madame Yun). The Kyujanggak Archive. Karam ko 920.7-G422y.

handwriting in the circles of women of their household. Although Chosŏn society prescribed strict gender segregation that was supposed to commence when the children reached the age of seven se, as numerous extant records intimate, boys and girls would often share in the same activities in the domestic space: some girls would teach themselves literary Chinese reading and poetry composition by overhearing their brothers' lessons, while boys would also participate in the pastime of their sisters.

Despite the evident fluidity and multidirectional exchange that occurred between male and female scribers and between vernacular Korean and literary Chinese calligraphic practices, I believe it useful to map the scriptural economy of Chosŏn along the lines of its gender politics. The vernacular Korean and literary Chinese culture-it must be emphasized-acquire gendered connotations not at the level of practice but at the level of social visibility, as part of prescriptive gender identities that outline a socially valuable repertoire of activities to men and women. Vernacular Korean proficiency added little prestige to men, and women's literary Chinese learning, while not unusual, fell out of the spectrum of desired womanly accomplishments.

As John Hay (1983), an art historian of China, has noted, calligraphy was viewed as an embodiment of a person's moral character. Vigorous, unclouded spirit revealed itself in measured, powerful brushstrokes, inscribing the bodily performance of the act of writing at the center of evenly ordered macrocosm. Careful attention to calligraphic training put under scrutiny the bodily comportment that accompanied this practice, and writing implements also became objects of connoisseurship. Yi Tŏngmu (2000, 257:485), in his manual for daily comportment, Sasojŏl 士小節 (Fine manners for gentlemen), strongly discouraged men from spitting onto their ink stones instead of using water 
when making ink. Yi also captured his fascination with writing implements in such poems as Chuk p'ilt'ong myŏng 竹筆筒銘 (Ode to a bamboo brush holder) or Humok yŏn'gap myŏng 朽木硯匣銘 (Ode to the ink stone case of old wood). In the latter poem, the worn exterior of the old wooden ink stone case makes it unappealing to vulgar people, but to a knower it reveals the untiring work of calligraphic training that lasts a lifetime (257:86-87). For men, their prowess in literary Chinese writing was an important part of their public identity, and it was interlaced with the task of moral cultivation and the social dimension of etiquette and shared connoisseurship practice.

In the case of women's practice of vernacular calligraphy, its aesthetic dimension was similarly imbued with aspects of moral and social significance. Importantly, womanly work, or gender-marked productive bodily discipline, was a category with moral valence that created foundations for self-worth and social respect. And while women's practice of connoisseurship might not have mustered an extensive list of objects and manners, we can see that women too had their own aesthetic circles, passing around the letters of their fellow calligraphers, sharing sketchbooks for the development of their calligraphic practice, and also, as I will show in the section that ensues, creating intrafamilial lines of manuscript transmission that perpetuated the memory of skilled calligraphers across the multiple generations of their families. When men refuse to discern the contours of women's extensive aesthetic practice beyond the "orderly brushstrokes," they perpetuate the logic of the patriarchal society that presumes a single organizing center of male literary Chinese culture. A closer look at the surviving artifacts of women's handwriting and the recognition of the gendered logic of representation in men's texts reveals that women's culture, too, became a unique organizing pole for an array of aesthetic, moral, and social practices consolidated within the domain of vernacular Korean calligraphy.

The apparent pride that women took in vernacular culture becomes strikingly apparent in a letter that Madame Kim of Andong addressed to her son, Song Ikhŭm (1708-57): "What is so hard about writing three-four letters in vernacular that you have to write your letter in literary Chinese?" (quoted in Chŏng Poktong 2013, 142). Known better as Kim Hoyŏnjae (1681-1772), Madame Kim left a sizable body of literary Chinese poetry, while her epistles are masterpieces of vernacular brushwork (see figure 1). Herself amply proficient in literary Chinese, Madame Kim, strikingly, insisted on the use of the vernacular Korean script in correspondence with her son, thus staking the boundaries of women's cultural space that, rather than an outlying province outside literary Chinese culture, was proudly acknowledged as the domain of women's choice and making.

\section{Vernacular Korean Calligraphy and Literary Production}

In the space of literary production, women's vernacular Korean calligraphy played an important role in defining the cultural prestige of a particular genre-the lineage novel (kamun sosŏl 家門小説), which formed the vernacular canon of elite literature beginning in the seventeenth century ( $\operatorname{Im}$ 1988). Tens and sometimes hundreds of manuscript volumes in length, lineage novels center on multiple generations of established lineages of civil officials. Branching out in the manner of genealogical trees to trace the lives of ever-new descendants of the patriline, lineage novels embody the idea of generational 
stability of the patriarchy in their very structure. The main focus of these texts, however, is on the plots of feelings. Lineage novels problematize the instances of violent contradiction between normative ideology and private self-perception. During the late seventeenth century, when the lineage novel emerged, premodern Korean society was transformed into a patriarchal structure with patrilineal succession. Lineage novels, thus, problematize the contradictions within individual lives that this transformation produced. Struggle for succession privilege between the older and younger sons within the structure of primogeniture, conflict in women's allegiance to natal and in-law families within patrilocal marriage arrangement, and, finally, the plight of the patriarchs responsible for the harmonious functioning of their households - on the pages of lineage novels, these contradictions are transformed from matters of ideology in theory into violent plots of tears and blood that allow readers to investigate the vagaries of unruly feelings and recognize their momentous presence in the fabric of society.

A concise overview of Choson book culture with particular attention to the lineage novel appears in Hong Hŭibok's (1794-1859) preface to the vernacular translation of Li Ruzhen's Jing hua yuan 鏡花緣 (Flowers in the mirror). A court interpreter and an avid reader of vernacular fiction, Hong used the general title "vernacular fiction" (̌nnmun sosŏl $)^{13}$ in his preface, but he mentioned several of the lineage novels' titles, which clarified the object of his description:

All these novels are of massive size, some longer than a hundred volumes, other ones a few tens, the shortest being around ten volumes in length. The number of these novels must be thirty or forty. Indeed, there are other, lowly novels - the kind of The Tale of Sukhyang (Sukhyang chŏn 淑香傳) or The Tale of Wind and Rain (P’ung'u chŏn 風雨傳). They are written in the common vulgar language, carved in lowly clumsy letters in woodblock and sold at the market. I will not be able to record the titles of all of them. (Hong Hŭibok 2001, 22)

The chief distinctions between the two types of vernacular fiction here are the mode of circulation, the length, and the material quality of the book. Hong dismisses as entirely insignificant the variety of fiction written in "crude letters" and sold at the marketplace, and this suggests that Hong and his contemporaries were wont to distinguish crude letters from refined handwriting.

A striking fact that calls attention to the crucial role played by women calligraphers in establishing the social prestige of the lineage novel is that in the absence of a single known

\footnotetext{
${ }^{13}$ Curiously, even while distinguishing lineage novels from other types of shorter novels, Hong Hŭibok subscribed to the generally negative view of the novel shared by Chosonn men of letters. In the very first lines of the preface, he established the utter inferiority of novels to classics and histories. Among the extant references to the lineage novel, this is the only one that treats these texts with suspicion. One possible explanation for this fact is that Hong Hŭibok read lineage novels as entertaining vernacular works. He was also a commoner, and we do not know of the tradition of extensive women's learning in commoner households. On the other hand, elite men of letters who wrote about lineage novels connected these texts to the learning and scribal practices of their kinswomen, which in their eyes endowed these manuscripts with great value. This underscores the significance of women's calligraphic practice in creating the prestige of the lineage novel as a genre of elite vernacular culture.
} 
author, the names of women calligraphers were frequently recorded on the novels' margins alongside praise of their skill and work. Too long and complex to be reproduced in woodblock editions, lineage novels relied on women's scribal activity and the existence of kinship networks for their circulation. This underscores the prominent role that women played in the culture of Chosŏn as calligraphers and readers.

Collectively produced by, and circulated among, kinswomen, lineage novel manuscripts were regarded as valuable tokens of the family's refinement. Among the very few extant external references to vernacular lineage novels, the earliest one belongs to Kwŏn Sŏp (1671-1759), who wrote that both his grandmother, Madame Yi of Sŏngp’yŏng (1622-63), and his mother, Madame Yi of Yongin (1652-1712), hand-copied lineage novels and consigned them to the care of their family members (quoted in Pak 1995, 322). The Andong Kwons were not a family of great means or social prestige, but they were a family of learning, and the tradition of copying and reading lineage novels was continued by generations of women who were born in, or married into, the Kwŏn family. Kwŏn Chinŭng (1711-75), Kwŏn Sŏp’s grandson, eloquently recorded the status of esteem that lineage novel manuscripts continued to possess in his family. Kwŏn Chinŭng wrote the following about his mother, Madame Song of Onp’il (1676-1737):

Alas! There remained letters of greeting written in my mother's hand, which she exchanged with my father, but Record of the Three Generations of the Han Lineage (Hanssi samdaerok 韓氏三代錄) is the only single book that survives. Sadly, the book has been damaged by mice and more than half of it was ruined and torn beyond repair. Still, lines after lines of my mother's handwriting survive as mementos of the days now past. Alas! How dare I read this book again? And how could I shamelessly abandon this volume, even for a day, so that it came to this dire condition? Finally, after repairing the worn patches, supplementing the missing parts, and refurbishing its binding and cover, I wrote on the title page "Ink of the Deceased" (Sornmok 先墨). Now I am writing down these circumstances to reflect on my own stupidity and to give a warning to young children so that they refrain from repeating my foolishness of ruining a book. (quoted in Pak 1995, 324-25)

The ruined volume is even more precious as it contains the handwriting of Kwŏn Chinŭng's maternal uncle-it was known to Kwŏn that the two siblings copied the volume together in their youth, this fact underscoring the fluidity of gender boundaries of vernacular culture. Reproaching himself for negligence that caused the ruin of the precious volume, Kwŏn Chinŭng, importantly, establishes the prestige of lineage novel manuscripts over letters. Kwŏn Chinŭng’s text thus highlights the intersection of women's vernacular calligraphy, literary production, and the mode of private memory-making through intrafamilial preservation of writings.

It was, however, among kinswomen that lineage novel manuscripts turned into objects of most intimate significance. A unique artifact of intergenerational readership is the manuscript of Ogwŏn chaehap kiyon 玉鴐再合奇缘 (The remarkable reunion of jade mandarin ducks), produced in the family of Madame Chŏng of Onyang (1725-99) (see figure 3). Written mostly in the hand of Madame Chŏng, the manuscript contains margin marks by other women from her family, who express their pleasure at beholding 


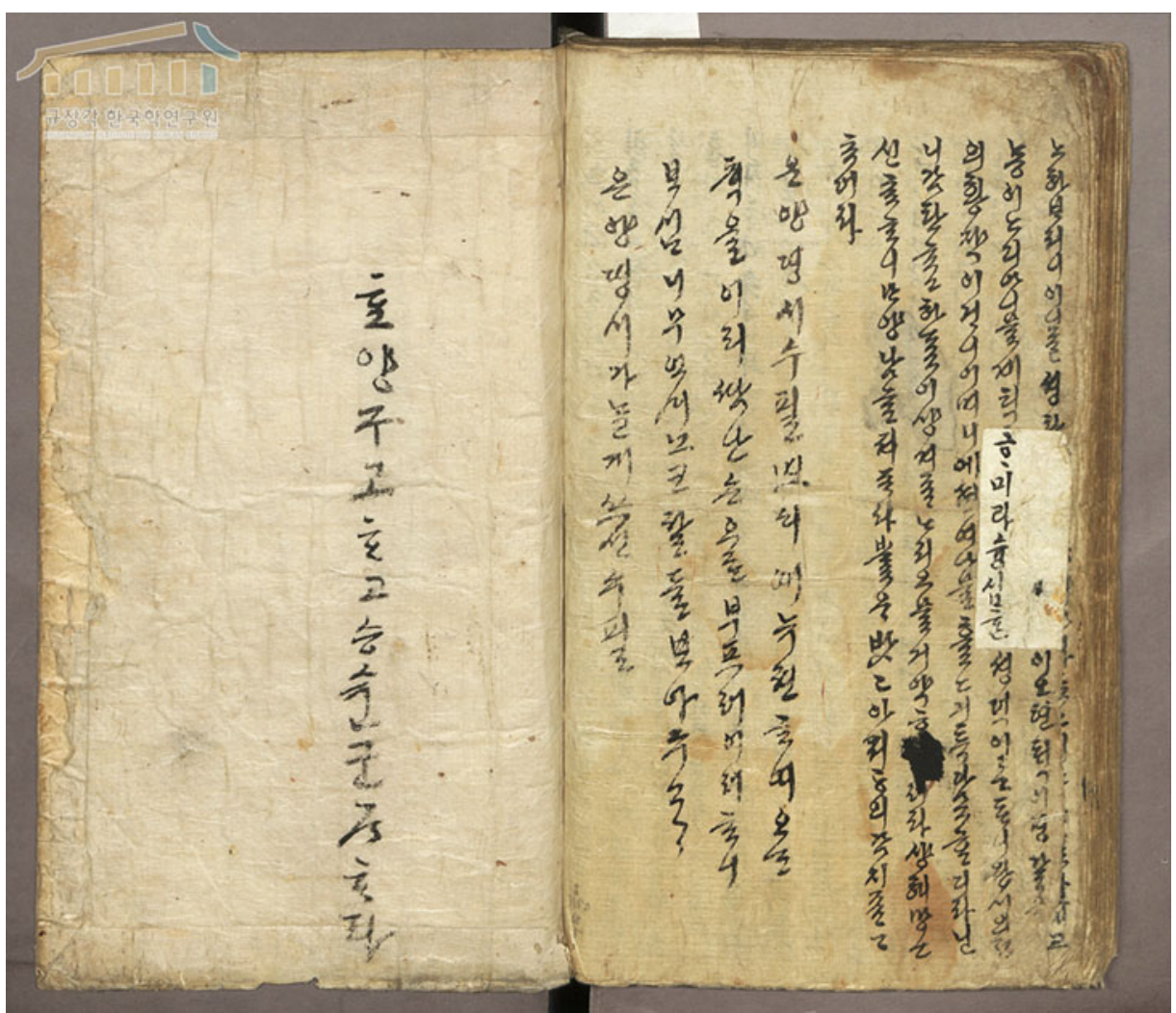

Figure 3. Ogwŏn chaehap kiyŏn (The remarkable reunion of jade mandarin ducks). The Kyujanggak Archive. Ko 3350-68.

the brushstrokes of the now deceased. An anonymous remark on the margin reads: "The handwriting belongs to Madame Chŏng of Onyang. This is a book that has been preserved and transmitted across several generations. If your hands are damp with sweat, do not just thumb through this book, but wrap [your hands] in something before holding it. The exquisite handwriting of Madame Chŏng of Onyang" (Ogwŏn chaehapkiyŏn, n.d.; also cited in Sim Kyŏngho 1990, 178; see figure 4). Generational intertextuality is also embedded in another undated and anonymous manuscript of Hyŏnssi yangung ssangnin'gi 玄氏兩雄雙麟記 (The record of two heroes: Brothers Hyŏn). A margin note reads: "This tale contains my eighty-year-old mother's writing, combined with the gem-like, exquisite handwriting of my nieces and my nephews' wives. Would anyone recognize their writing later? It is unfortunate that the pearl-like letters of the mothers are so scarce...." (quoted in Yi Tawŏn 2001, 16)

Women's participation in the literary culture of traditional Korea becomes even more intriguing in the light of a remark left by Cho Chaesam (1808-66) in his encyclopedic miscellany Songnam chapchi 松南雜識 (The miscellaneous records of Songnam). Cho wrote, "It is said that Moon-Gazing (Wanwŏl 玩月) is written by the mother of An Kyŏmje-she wanted to circulate it inside the inner palace to increase her fame" (quoted in Jung 1998, 175). Wanwŏlhoe maengyŏn 玩月會盟宴 (The pledge at the 


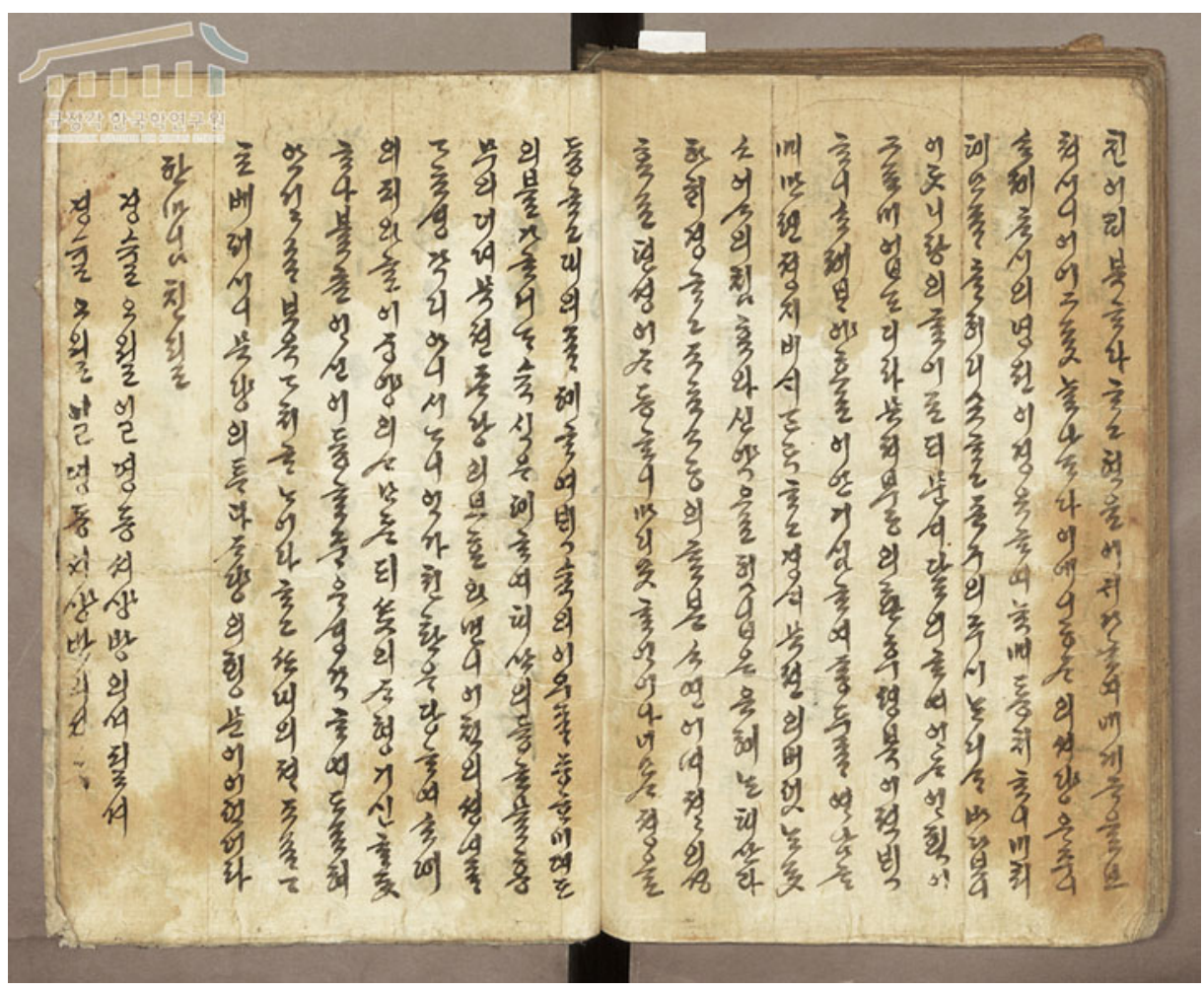

Figure 4. Ogwŏn chaehap kiyŏn (The remarkable reunion of jade mandarin ducks). The Kyujanggak Archive. Ko 3350-68.

banquet of moon-gazing pavilion), with its 180 manuscript volumes, is among the longest novels in the premodern Korean canon, and such an abbreviated reference to the author of this massive work is intriguing. However, the journal's imprecision regarding other attributions casts doubt on the credibility of the statement of Madame Yi's authorship. ${ }^{14}$ Madame Yi of Chŏnju (1694-1743), the mother of An Kyŏmje, is indeed a historical person who grew up in, and married into, an elite, if somewhat less prominent lineage. In terms of her class and education, the authorship of Madame Yi of Chŏnju appears plausible, ${ }^{15}$ but the question of the ultimate credibility of Cho Chaesam's note remains unresolved without further evidence. ${ }^{16}$

The prestige of the author title that celebrates an individual act of imaginative creation is a historical invention of modern Western culture. While not a single author of a lineage novel is confirmed, we might surmise that many of them were men, as it was

\footnotetext{
${ }^{14}$ Cho Chaesam misattributes the two novels written by Kim Manjung, Nine-cloud dream and Madame Sa's conquest of the south, to the author's nephew, Kim Ch'unt'aek (see Cho 1987, 2419).

${ }^{15}$ Based on the writings that describe the education of the women of the Chŏnju Yis, Han Kilyŏn (2005) attempts to substantiate the claim that women of this family indeed possessed sufficient knowledge and training to possibly be the collegiate authors of The pledge.

${ }^{16}$ Jung Byung-sul (1997) was the first to propose Madame Yi of Chŏnju as the author of The pledge, and possibly of another lineage novel, The remarkable reunion of jade mandarin ducks.
} 
indeed not uncommon for men to write fiction, both in literary Chinese and in vernacular Korean. It is, however, important to recognize an alternative aspect of authorship that becomes most apparent in women's scribal activities. By creating the exquisite, masterfully executed manuscripts of lineage novels, women added the dimension of material significance to these texts. For much of their history, lineage novels circulated exclusively in the form of family-transmitted manuscripts, ${ }^{17}$ and through women's skilled handiwork these manuscripts became specimens of fine calligraphy and also objects of sentimental value that captured the brushstrokes of the deceased scribers. The materiality of the lineage novel powerfully emerges in men’s writing-Kwŏn Sŏp and Kwŏn Chinŭng both focus on the process of transcribing and transmitting the novels even as they mention nothing at all regarding these texts' contents. Along these lines, I believe it is possible to inaugurate women scribers of Chosonn as authors in their own right: these women authored the material foundation of elite vernacular culture of Chosŏn, creatively interpreting the gender norms of their time and interweaving them with creative self-expression. The vernacular calligraphy, which gained social and aesthetic recognition in women's practice, as part of an extended repertoire of women's bodily competences within the moral framework of womanly work, points to a creative center of vernacular culture, located in women's quarters. Here, we discern not just a few maverick women, who left their paintings, writings, and even Confucian scholarship (Kim-Renaud 2004), but an extensive cultural realm created and sustained by women.

\section{In CONCLUSION}

In South Korea's contemporary scholarship and cultural projects, vernacular or palace-style brushwork has long been accepted as a full-fledged calligraphic practice (see, e.g., Yesul ŭi chŏndang 1994), celebrated for its indigenous origins as opposed to the literary Chinese calligraphy. In this, we can certainly discern an extended decolonizing project that stretches from Japan's annexation of Korea in the early twentieth century, reinforced in the post-liberation historical scholarship. On the verge of colonization, it became the primary task of Korean nationalist intellectuals to disentangle the indigenous culture from the Confucian system founded upon the literary Chinese canon, seen as a foreign "borrowing" that stifled "native" creative impulses (Schmid 2002, 55-138).

While this article is similarly suggesting that the practice of vernacular brushwork was calligraphic, with a host of connotations of aesthetic value, cultural prestige, and social meaning that this term would suggest, it proposes a different relationship between vernacular culture and the hegemonic Confucian system and literary Chinese. It is important to acknowledge the very intimate relationship vernacular Korean calligraphy had with the Confucian gender norms that linked bodily discipline, womanly work, and refined vernacular handwriting. Similarly, the boundaries between vernacular and literary Chinese culture were quite porous, since elite men were versed in vernacular Korean, while elite women could similarly read and write literary

\footnotetext{
${ }^{17}$ Circulating exclusively in family-transmitted manuscripts for most of their history, lineage novels entered lending libraries around the turn of the twentieth century. Chŏng Myŏnggi (2003) discusses rental libraries' catalogs that include lineage novels' titles.
} 
Chinese. Finally, it is owing to men's accounts of women's vernacular practices that we can reconstruct the contours of elite vernacular culture.

The recognition of an elite vernacular canon calls for the revaluation of the historical context in which it developed. In her book on the emergence of women as readers, writers, and overall significant cultural actors in early twentieth-century Korea, Ji-Eun Lee $(2015,24)$ writes the following about women's culture in Chosŏn: “women’s social and familial status created an adverse environment for the growth of a full-fledged female readership by preventing women from forming a class of readers who could freely choose their reading material, form their own tastes, and influence a literary market." Although, admittedly, Lee focuses on women's reading practices, I believe we can read this as a statement on the overarching gender politics of the Chosorn state, which circumscribed women's access to all forms of culture. Lee correctly observes that Chosŏn Korea knew nothing of a vibrant literary market and women-centered novelistic tradition, crucial to the emergence of modern literary culture and sensibility in Europe (Armstrong 1987). This article, however, has shown that we can observe womencentered tradition configured around the rigidly legislated ideal of women's domesticity, creatively reengaged. Importantly, this article also allows us to see that Korea's vernacular culture-much in excess of its purely demotic connotations that dominate the historical thinking on this topic - was actually stratified after the emergence of the exclusive, elite form of vernacular practices that not only required time and means to master, but also rested on the recognition of the cultural value of women's learning.

My reading of women's creative presence beneath the script of patriarchal authority is inspired by Hui-Shu Lee $(2010,56-57)$, a China historian, who unravels the gendered system of representation in Song-dynasty art. Lee, for instance, shows how, through a series of fellowships and negotiations, women carved out a space for their own creative practice-like the palace women who acted as ghost scribes for emperor Gaozong $(r$. 1127-62), whose calligraphy entered the aesthetic space under his name. In the case of Chosŏn, similarly, the gendered logic that governed men's representations of women's lives - if deciphered-reveals that the Confucian patriarchy of Chosŏn was a carefully and rigorously constructed model of people's relationships that was open to maneuverability — an advantage, which elite women, as we see, have freely availed themselves of to become active producers of culture.

Lastly, a note is due on the nature and the historical fate of the Korean vernacular canon. Canon formation is commonly understood as a process of exclusion and empowerment in which a particular group of people perpetuates and valorizes its cultural capital. In this view, Korean vernacular practices did not quite coalesce into a canon, having circulated in narrow, familial groups of women who did not have access to the public space of connoisseurship and exchange outside the domestic realm. John Guillory (1993, 16), however, has offered a compelling rethinking of canonicity, suggesting that "the most socially consequential process of exclusion occurs primarily at the level of access to literacy." In other words, canonicity inheres not in the relationship between canonical and noncanonical works, but within the sociohistorical aspect of writing, to which some groups are admitted and some are not.

The rise of the vernacular canon in Chosŏn should be understood precisely in terms of the access to literacy and aesthetic cultivation that it opened for women, whose social identities were predominantly evaluated on the basis of the productive bodily work they 
performed. The emergence of the lineage novel and of vernacular Korean calligraphy expanded the range of women's bodily competences to include the element of aesthetic cultivation, which in turn contributed to the prestige of their families. Quite unlike the Chinese vernacular that was monopolized by elite men or, in Japan's case, in which vernacular forms of literature were canonized early in history and were enjoyed by men and women, in Chosŏn Korea, vernacular cultural production was closely entangled with women's roles in the patriarchal kinship structure and the ideal of women's domesticity and bodily discipline it prescribed.

\section{Acknowledgments}

I am deeply grateful to Dorothy Ko and Jungwon Kim, who read multiple drafts of this manuscript and suggested a number of crucial improvements. Without the generous guidance of Professor Lim Chee-kyun of the Academy of Korean Studies my work on the lineage novel would not have been possible at all. The anonymous reviews of this work were astonishingly deep and detailed, helping develop it much beyond its original shape, and I thank the editor, Professor Jeffrey Wasserstrom, for his patience. The generous monetary support that enabled this work came from a Korea Foundation grant for field research, an Academy of Korean Studies graduate fellowship, and Australian National University's postdoctoral fellowship. The institutional support from the Kyujanggak was crucial at the early stages of the research while later revisions, done in Canberra, were greatly facilitated by the hospitality of ANU's Korea Institute.

\section{List of References}

Academy of Korean Studies, ed. 1992. Arŭmtaun kŭlja han'gŭl [The beautiful letters of Han'gŭl]. Seoul: Ewha munhwasa.

. 2000. Changsŏgak han'gŭl charyo haeje [Annotated catalogue of vernacular Korean holdings of the Changsoggak archive]. Songnam: Academy of Korean Studies Press.

Armstrong, Nancy. 1987. Desire and Domestic Fiction: A Political History of the Novel. Oxford: Oxford University Press.

Bray, Francesca. 1997. Technology and Gender: Fabrics of Power in Late Imperial China. Berkeley: University of California Press.

Cho Chaesam. 1987. Songnam chapchi [The miscellaneous records of Songnam]. Edited by Im Kijung. Seoul: Tongsŏ munhwawŏn.

Ch’oe, Yŏngho, trans. 1993. "King Sejong: Preface to Correct Sounds to Instruct the People." In Sourcebook of Korean Civilization, ed. Peter H. Lee, 1:295. New York: Columbia University Press.

ChǑNG HYǒngJi et al., eds. 2006. 17 segi yŏsŏng saenghwalsa charyojip [Sources on the lives of women in the seventeenth century]. Vols. 1-4. Seoul: Pogosa.

ChŎNG MyŏngGi. 2003. “Sech’aekbon sosŏl ŭi yut’ong yangsang. Tongyang mun'go sojang sech'aekbon sosŏl e nat'anan sech'aekpu rŭl chungsim ŭro" [Circulation of rental books: The case of catalogs [recorded] inside rental books of the Tōyō bunko]. Kososŏl yŏn'gu 16:71-99.

ChŎNG Poktong. 2013. “Osukche Song Ikhŭm ŏn'gan sŏch'e ŭi hyŏngsŏng kwa chohyŏngsŏng koch'al" [The formation and style of Song Ikhŭm's calligraphy in his letters in the vernacular Korean script]. Sŏyehak yŏn'gu 22:135-68. 
Chŏng TAнам. 2009. “Yŏmal Sŏnch’o ŭi Tongasia chilsŏ wa Chosŏn eso ŭi Hanŏ, Hansamun, Hunmin chŏngŭm” [The East Asian world order, the literary Chinese culture, and vernacular Korean during the late Koryŏ and early Chosŏn]. Han'guksa hakpo 36:269-305.

Deuchler, Martina. 1992. The Confucian Transformation of Korea: A Study of Society and Ideology. Cambridge, Mass.: Harvard University Asia Center.

—. 2003. "Propagating Female Virtues in Chosŏn Korea." In Women and Confucian Cultures in Premodern China, Korea, and Japan, eds. Dorothy Ko and JaHyun Kim Haboush, 142-69. Berkeley: University of California Press.

Guillory, John. 1993. Cultural Capital: The Problem of Literary Canon Formation. Chicago: University of Chicago Press.

Haboush, JaHyun Kim. 2002. "Gender and Politics of Language in Chosŏn Korea.” In Rethinking Confucianism: Past and Present in China, Japan, Korea, and Vietnam, eds. Benjamin A. Elman and John B. Duncan, 220-56. Berkeley: University of California Press.

. 2008. "The Vanished Women of Korea: The Anonymity of Texts and the Historicity of Subjects." In Servants of the Dynasty: Palace Women in World History, ed. Ann Walthall, 280-98. Berkeley: University of California Press.

—, ed. 2009. Epistolary Korea: Letters in the Communicative Space of the Chosŏn, 1392-1910. New York: Columbia University Press.

Han KILYŏN. 2005. "Paekkye yangmun sŏnhaengnok ŭi chakka wa kŭ chubyŏn. Chŏnju Yissi kamun yŏsŏng ŭi taehasosŏl ch'angjak kanŭngsŏng ŭl chungsim ŭro" [The author and the social context of Record of good deeds of two households: Paek and Kye. Women of the Chŏnju Yi family as potential authors of lineage novels]. Kojŏn munhak yŏn'gu 27:329-61.

Hanan, Patrick. 1981. The Chinese Vernacular Story. Cambridge, Mass.: Harvard University Press.

HaY, John. 1983. "The Human Body as a Microcosmic Source of Macrocosmic Values in Calligraphy." In Theories of the Arts in China, eds. Susan Bush and Christian Murck, 74-102. Princeton, N.J.: Princeton University Press.

Hong HaKhŬI et al., eds. 2013. 19 segi 20 segi ch'o yŏsŏng saenghwalsa charyojip [Sources on the lives of women in the nineteenth and early twentieth centuries]. Vols. 1-9. Seoul: Pogosa.

Hong Нǔıвок. 2001. "Cheilgiŏn sŏ” [Preface to Flowers in the mirror]. In Cheilgiŏn [Flowers in the mirror], eds. Pak Chaeyŏn and Chŏng Kyubok. Seoul: Kukhak charyowŏn.

Hwang SuYŏN et al., eds. 2010. 18 segi yŏsŏng saenghwalsa charyojip [Sources on the lives of women in the eighteenth century]. Vols. 1-8. Seoul: Pogosa.

Iм HYŏNGT’AEK. 1988. “17 segi kyubang sosŏl ŭi songnipkwa Ch’angsŏn kamŭirok” [Praise of goodness and commendation of righteousness and the rise of female readership of the novel]. Tongbanghakji 57:103-76.

Jung Byung-Sul. 1997. "Ogwŏn chaehap kiyŏn chakka chaeron: Chosŏn hugi yŏsŏng sosŏlga ŭi han kŏn'ye" [Reconsidering the authorship of The remarkable reunion of jade mandarin ducks: The case of one late-Chosŏn female author]. Kwanak ómunhak yŏn'gu 22:317-32.

Jung Byung-Sul. 1998. Wanwŏlhoe maengyŏn yŏn'gu [A study of The pledge at the banquet of moon-gazing pavilion]. Seoul: T’aehaksa. 
KIm ILGǓN. 1971. Ŏn'gan ŭi yŏn'gu: han'gŭl sŏch'al ŭi yŏn'gu wa chipsŏng [A study of vernacular Korean letters: Interpretation and collection of sources]. Seoul: Konkuk University Press.

KIM, Jisoo M. 2015. The Emotions of Justice: Gender, Status, and Legal Performance in Chosŏn Korea. Seattle: University of Washington Press.

Kim Tonguk. 1971. "Yijo sosŏl ŭi chŏja wa tokcha e taehayŏ" [Readership and authorship of Chosŏn-dynasty novels]. In Changam Chi Hŏnyŏng sŏnsaeng hwagap kinyŏm nonch'ong [Papers offered to Professor Chi Hŏnyŏng on his sixtieth anniversary]. Seoul: Hosŏ munhwasa.

KIm Yongsuk. 1987. Chosŏnjo kungjung p'ungsok yŏn'gu [Customs of the Chosŏn court]. Seoul: Ilchisa.

Kim-Renaud, Young-Key, ed. 2004. Creative Women of Korea: The Fifteenth through the Twentieth Centuries. Armonk, N.Y.: M.E. Sharpe.

Lee, Hui-Shu. 2010. Empresses, Art, \& Agency in Song Dynasty China. Seattle: University of Washington Press.

LeE, Ji-Eun. 2015. Women Pre-Scripted: Forging Modern Roles through Korean Print. Honolulu: University of Hawai'i Press.

OGWŎN CHAEHAPKIYǑN. n.d. The Kyujanggak Archive, Seoul National University, South Korea. Ko 5:3350-68.

PAK YŏNGHǓI. 1995. “Changp'yŏn kamun sosŏl ŭi hyang’yu chiptan yŏn'gu” [Readership of the lineage novel]. In Munhak kwa sahoe chipdan [Literature and society], ed. Han'guk kojŏn munhakhoe, 319-61. Seoul: Chimmundang.

Pollock, Sheldon. 2006. The Language of the Gods in the World of Men: Sanskrit, Culture, and Power in Premodern India. Berkeley: University of California Press.

Schmid, ANDre. 2002. Korea between Empires, 1895-1919. New York: Columbia University Press.

Scott, Joan Wallach. 1999. Gender and the Politics of History. New York: Columbia University Press.

Shirane, Haruo. 2003. "Canon Formation in Japan: Genre, Gender, Popular Culture, and Nationalism." In Reading East Asian Writing: The Limits of Literary Theory, eds. Michel Hockx and Ivo Smits, 22-38. London: RoutledgeCurzon.

Sıм HyŏNsŏr. 2009. "Chosŏn sŏnbi dŭl ŭi sŏye insik kwa kyoyuk" [Calligraphy in the life of Chosŏn scholars: Its meaning and training]. Sŏyehak yŏn'gu 15:37-77.

Sim KYŏNGHO. 1990. “Naksŏnjaebon sosŏl ŭi sŏnhaengbon e kwanhan il koch’al—Onyang Chŏngssi p’ilsabon Ogwŏn chaehapkiyŏn kwa Naksŏnjaebon Ogwŏn chunghoeyŏn ŭi kwan'gye rŭl chungsim ŭro" [A study of the manuscripts of the Naksonnjae novels: The relationship between Ogwŏn chaehapkiyŏn copied by Madame Chŏng of Onyang and the Naksŏnjae manuscript of Ogwŏn chunghoeyŏn]. Chŏngsinmunhwa yŏn'gu 38:169-88.

Song SiYǑL. 2000. "Instruction to My Daughter." Translated by JaHyun Kim Haboush. In Sources of Korean Tradition, eds. Yŏn-ho Ch’oe et al., 2:49-52. New York: Columbia University Press.

Wang, Sixiang. 2012. "The Filial Daughter of Kwaksan: Finger Severing, Confucian Virtues, and Envoy Poetry in Early Chosŏn." Seoul Journal of Korean Studies 25 (2):175-212.

YESUL ŬI CHǑNDANG, ed. 1994. Chosŏn sidae han'gŭl sŏye [Vernacular Korean calligraphy of the Chosŏn dynasty]. Seoul: Mijinsa.

YI INSUk. 2005. "Chosŏn sidae hanmun kanch'al ŭi sŏyesa chŏk ŭiǔi”" [The calligraphic significance of literary Chinese epistles in Chosŏn dynasty]. Sŏyehak yŏn'gu 6: 51-81. 
YI KYǑNGHA. 2005. "17 segi sangch’ŭng yǒsŏng ŭi kungmun saenghwal e kwanhan munhŏn chŏk koch'al” [Overview of sources on women's use of vernacular Korean script in the seventeenth century]. Han'guk munhak nonch'ong 39:217-41.

YI TAWŎN. 2001. “Hyŏnssi yangung ssangnin'gi yŏn'gu: Yŏndaebon Hyŏnssi yangung ssangnin'gi chungsimŭro" [Study of the record about two heroes: Brothers Hyŏn, with a focus on the Yonsei University manuscript]. PhD diss., Yonsei University.

YI TŏNGmu. 2000. "Chŏngjanggwan chŏnsǒ" [The complete literary collection of Yi Tŏngmu]. In Han'guk munjip ch'onggan [The complete compendium of Korean literary collections], ed. Minjok munhwa ch’ujinhoe, vols. 257-59. Seoul: Minjok munhwa ch'ujinhoe.

Yunssi haengjang [Posthumous biography of Madame Yun]. n.d. The Kyujanggak Archive, Seoul National University, South Korea. Karam ko 920.7-G422y. 